Formatted: Left: $2.5 \mathrm{~cm}$, Right: 2.5 $\mathrm{cm}$, Different first page header

Formatted: Font: (Default) Arial, Bold, Font color: Auto, Complex Script Font: Arial, 16 pt, Bold, Kern at 16 pt

Formatted: Left-to-right, Space After: 3 pt, Don't keep lines together

Formatted: Font: (Default) Arial, Font color: Auto, Complex Script Font: Arial,

$16 \mathrm{pt}$, Kern at $16 \mathrm{pt}$

\begin{tabular}{|c|}
\hline ... matted \\
\hline ... matted \\
\hline$\ldots$ matted \\
\hline Formatted: Line spacing: single \\
\hline ... matted \\
\hline ... matted \\
\hline ... matted \\
\hline ... matted \\
\hline Formatted: Line spacing: single \\
\hline ... matted \\
\hline$\ldots$ matted \\
\hline ... matted \\
\hline ... matted \\
\hline ... matted \\
\hline$\ldots$ matted \\
\hline ... matted \\
\hline$\ldots$ matted \\
\hline ... matted \\
\hline ... matted \\
\hline ... matted \\
\hline ... matted \\
\hline Formatted: Centered \\
\hline ... matted \\
\hline ... matted \\
\hline Formatted: Line spacing: single \\
\hline ... matted \\
\hline ... matted \\
\hline ... matted \\
\hline ... matted \\
\hline ... matted \\
\hline ... matted \\
\hline ... matted \\
\hline ... matted \\
\hline ... matted \\
\hline ... matted \\
\hline ... matted \\
\hline ... matted \\
\hline ... matted \\
\hline
\end{tabular}

Journal of Al Azhar University Engineering Sector Vol. 11, No. 38, January, 2016, 125-138

JAUES

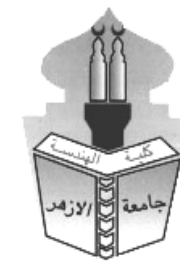

\section{GIS-BASED AHP-OWA APPROACH FOR LOCATING SUITA SITES FOR WATER HARVESTING DAM IN QASSIM REGII SAUDI ARABIA}

\author{
Ranim AlJubaely ${ }_{\Delta,}^{1}$, Ahmed H. Soliman $_{\alpha}^{2^{4}}$, Khaled Hamed $_{A,}^{3}$, and Alaa El-Zawah \\ Cairo University, Faculty of Engineering, Department of Irrigation and Hydraul
} $\rightarrow$ $\rightarrow$

ع سدود حصاد المياه هو عملية اتخاذ قرار معقدة. حيث إن إيجاد الموقع الأفضل بتطلب دمج تقنية المعايير

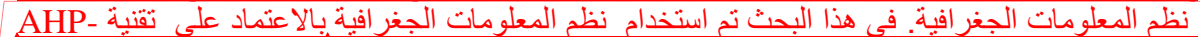

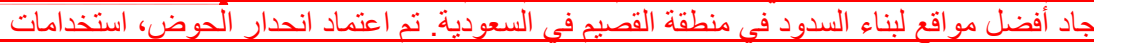

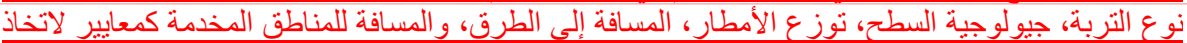

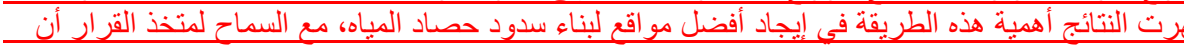
عتبار سيناريو هات مختلفة بين المتفائلة و المتشائمة.

\begin{abstract}
Selection of a water harvesting dam site involves a complex array of decision crit may have conflicting values. Finding the optimum location requires integration capacities of Geographic Information Systems (GIS) and Multi-criteria Decision(MCDM). In this paper, a GIS-based multi-criteria decision analysis approach is used this problem. The approach is based on the extension of Analytical Hierarchy Proct fuzzy quantifiers-guided Ordered Weighted Averaging operators (GIS-based AHF This approach is applied to determine the optimal site of a water harvest dam in region, Saudi Arabia. Several factors affect the selection of the best location of $\mathrm{t}$ ] water harvesting dam such as: slope, landuse, soil type, geology, rainfall, drainage distance from the road, and distance from the cities, are used. The results showed tha combination of GIS-based AHP-OWA is proper approach for optimal water harve: selection, where this approach provides a generic powerful decision-making tool thi decision-makers to define a decision strategy on a continuum between pessimis 1 averse) and optimistic (risk-taking) strategies.
\end{abstract}

KEYWORDS: $\quad$ Water harvesting site selection, Geographic Information Sy

${ }^{1}$ PhD Candidate, Cairo University, Faculty of Engineering, Department of Irrigation and Hydraulics, E-mail: ranim_aljubaely@yahoo.com.

${ }^{2}$ Assistant Professor, Cairo University, Faculty of Engineering, Department of Irrigation and Hydraulic a.soliman@cu.edu.eg

3 Professor of water resources, Cairo University, Faculty of Engineering, Department of Irrigation a। hamedkhaled@hotmail.com.

${ }^{4}$ Professor of Hydraulics, Cairo University, Faculty of Engineering, Department of Irrigation and, Email:alaa.zawahry@gmail.com. 
Formatted: Font: $8 \mathrm{pt}$, Not Bold, Complex Script Font: 8 pt, Not Bold

Formatted: Font: $1 \mathrm{pt}$, Complex Script Font: $1 \mathrm{pt}$

Formatted: (Complex) Arabic (Egypt)

Formatted: Font: Bold, Complex Script Font: Bold

Formatted: Font: 12 pt, Bold,

Complex Script Font: 12 pt, Bold

Formatted: Font: 12 pt, Bold,

Complex Script Font: 12 pt, Bold

Formatted: Font: Bold, Complex Script Font: Bold

Formatted: Font: $1 \mathrm{pt}$, Bold, Complex Script Font: 1 pt, Bold

Formatted: Line spacing: Exactly 12 pt

Formatted: Indent: Before: $0 \mathrm{~cm}$,

First line: $0 \mathrm{~cm}$, Line spacing: Exactly

$12 \mathrm{pt}$

Formatted: Indent: First line: $0 \mathrm{~cm}$ Line spacing: Exactly 12 pt
Formatted: Line spacing: Exactly 12 pt
GIS-BASED AHP-OWA APPROACH FOR LOCATING SUITABLE SITES FOR WATER HARVESTING DAM IN C REGION, SAUDI ARABIA

(GIS), Analytical Hierarchy Process (AHP), Ordered Weigh Averaging (OWA).

\section{$\rightarrow$ 1. INTRODUCTION}

$\rightarrow-$ Increasing demand of water due to growing population, with the difficulty of explo: some cases, cause intense pressure on available water resources. So it becomes nec harvest rainfall as the primary source of water, maximizing storage and minimizing of rainwater. Rainwater harvesting techniques have received growing attention, esp $\epsilon$ arid and semi-arid regions like Saudi Arabia. Rainwater harvesting and conservati activity of direct collection of rain. The collected water could be stored for direc recharged into the groundwater. It is the best means to get water when other water so not available.

One of the most important and complex problems in different countries is the selectic water harvesting site. A large amount of information should be gathered, combi1 analyzed to develop correct criteria which will affect the final decision. The problem $\mathrm{i}$ combine the criterion maps according to the attribute values and decision maker's pre using a set of decision rules. Geographic Information Systems (GIS) and Multicriteria Making (MCDM) techniques are the most common tools employed to solve these prob] each suffers from serious shortcomings. While GIS is a great tool for handling suitability analysis, but it has limited capabilities of incorporating the decision preferences into the problem solving process. On the other hand, MCDM is the proper analyzing decision problems and evaluating alternatives based on decision maker's va preferences. However, MCDM lacks the capability of handling spatial data (e.g., buffe overlay) that are crucial to spatial analysis. The need for combining the strengths techniques has prompted researchers to seek integration of GIS and MCDM.

A number of attempts had been implemented in the GIS environment over the last $\mathrm{d} \epsilon$ identifying the most appropriate sites for Water Harvesting Structures (WHS). For exar site suitability for different water harvesting structures was determined by considering varying parameters like runoff potential, soil type, slope, drainage network and land $\mathrm{u}$ the overlay and decision tree concepts in GIS [1]. Runoff coefficient, land use, so: drainage and stream order, soil permeability were considered in site selection 0 harvesting/recharging structures in [2] using Overlay in Analysis tools of GIS Ma] suitable of water harvest in Qassim region was done, through the overlay method of the soil, slope, rainfall, landuse, distance to roads, distance to cities criteria using raster c operation in GIS, adopting equal weight approach [3]. GIS and AHP was used for site s analysis of water harvesting Structures in Pisangan, different layers were taken into acr multi criteria evaluation are Soil texture, slope, rainfall data, land use/cover, geomor lithology, lineaments, drainage network [4]. In general, previous studies show the usi overlapping, or GIS-based AHP for choosing suitable sites for a rain water harvest. B and OWA procedures have been employed individually in GIS environments, each limitations. AHP used the pairwise comparison to calculate the weight of criteria, but it $\xi$ scenario, while OWA uses the fuzzy linguistic quantifier to gives several scenarios and rank method to evaluate the weight of criteria. Combining the strength of each method, . OWA can provide a more powerful multicriteria decision-making tool for structu solving spatial decision problems. In this paper, an efficient decision-making framework site selection is developed by integrating the strengths of GIS-based AHP-OWA the $\mathrm{e}$ of Analytical Hierarchy Process using fuzzy quantifiers-guided ordered weighted av This will allow decision-makers to define a decision strategy on a continuum pessimistic (risk-averse) and optimistic (risk-taking) strategies. By changing the 1 quantifiers, the GIS-based AHP-OWA approach provides a generic powerful decisior tool that allows decision-makers to generate a wide range of decision strategies.

\section{PROPOSED GIS-BASED MULTICRITERIA EVALUATION FRAMEW FOR SOLVING HARVEST DAM SITE SELECTION PROBLEMS:}


Formatted: Font: 8 pt, Not Bold, Complex Script Font: 8 pt, Not Bold

Formatted: Font: $1 \mathrm{pt}$, Complex Script Font: $1 \mathrm{pt}$

Formatted: (Complex) Arabic (Egypt)

Formatted: Indent: First line: $0 \mathrm{~cm}$ Line spacing: Exactly $12 \mathrm{pt}$
Formatted: Font: $10 \mathrm{pt}$ Bold Complex Script Font: 10 pt, Bold Formatted: Space After: 0 pt, Line spacing: single

Formatted: Indent: First line: $0 \mathrm{~cm}$ Line spacing: Exactly $12 \mathrm{pt}$
GIS-BASED AHP-OWA APPROACH FOR LOCATING SUITABLE SITES FOR WATER HARVESTING DAM INC REGION, SAUDI ARABIA

GIS-based Multi criteria Evaluation (GIS-MCE) can be defined as a process that integ transforms geographic data (map criteria) and value judgments (decision maker's prefer obtain overall assessment of the decision alternatives.

Four procedural steps of the proposed framework will be followed. (1) Defining , selection Criteria, (2) Preparing criterion map, (3) Data standardization, and (4) Mu] evaluation using AHP-OWA method. Figure (1) shows the steps of GIS-based MCE.

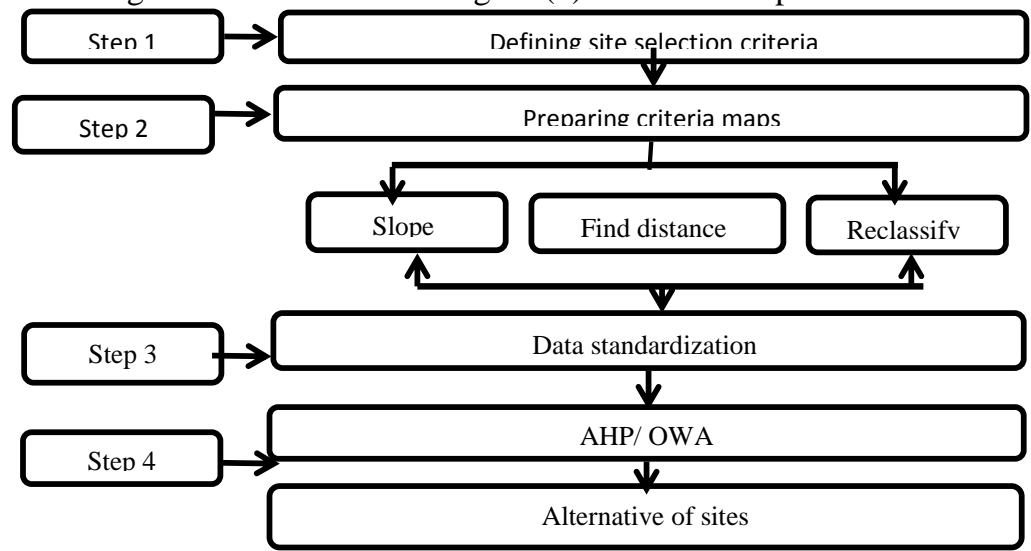

Fig.1.GIS-based MCE approach

To implement the proposed GIS-based MCE approach for dam site selection, a resear modified an present tool [5] to be used for dam site selection, using Visual Studio 2 Programming Language), as a toolbar within ArcGIS desktop to help the GIS an solve complex dam site selection problems. As shown in Figure (2) a dam Site : Toolbar is comprised of three main menus (data preparation, data standardization, a Tools)

\begin{tabular}{|c|c|c|c|}
\hline \multicolumn{4}{|c|}{ Dam Site Selection Using GIS-Based MCD } \\
\hline Data Standrization & AHP & OWA & AHP/OWA \\
\hline
\end{tabular}

Fig.2. Dam Site selection using GIS-based MCE toolbar.

$\rightarrow$ The steps of getting the suitability map of water harvesting dam using the tool are: $\rightarrow$ 2.1 Data Preparation:

$\rightarrow$ The first step after selecting the main criteria and sub-criteria of water harvesting generate their maps based on different GIS functions (slope, distance, etc..), and mal result maps have same pixel size and number.

\section{$\rightarrow \quad$ 2.2 Standardized Criterion Maps:}

- After preparing the criteria maps, and before aggregating the input layers in ar process, they must be on the same scale. The maps are created using raster format and ea layer contains the attribute values assigned to the alternatives, and each alternative related to the higher-level elements (i.e., attributes). For decision analysis, the values $c$ in the various criterion map layers are standardized to a common scale to reduce dimens The outcome of the function is always a value between 0 and 1 .

2.3 MCE tool:

After preparing the standardized criteria maps, the next step is using one of the MCE methods to identify the most suitable locations for rain water harvest (Analytical $\mathrm{F}$ Process (AHP), Order Weighted Averaging (OWA), and the extension of AHP usir operators.

\section{Literature of the AHP and OWA methods:}

\subsection{Analytical Hierarchy Process (AHP)}


Formatted: Font: $8 \mathrm{pt}$, Not Bold, Complex Script Font: 8 pt, Not Bold

Formatted: Font: $1 \mathrm{pt}$, Complex Script Font: $1 \mathrm{pt}$

Formatted: (Complex) Arabic (Egypt)
Formatted: Indent: First line: $0 \mathrm{~cm}$, Line spacing: Exactly $12 \mathrm{pt}$

Formatted: Line spacing: Exactly 12 pt

Formatted: Font: $12 \mathrm{pt}$, Complex Script Font: 12 pt
GIS-BASED AHP-OWA APPROACH FOR LOCATING SUITABLE SITES FOR WATER HARVESTING DAM IN C REGION, SAUDI ARABIA

The AHP is a powerful tool in applying MCDA that was introduced and deve Saaty [6]. It is based on decision making paired comparisons. The comparison of eac alternatives is evaluated according to the criteria and their relative weights. In $A$ decision-making process starts with dividing the problem into a hierarchy of issues. hierarchical level, the weights of the elements are calculated. The decision on the finc made considering the weights of criteria and alternatives.

The pairwise comparison method employs an underlying scale with odd values $f$ 9 to rate the relative preferences for two elements of the hierarchy. in some c intermediate values (i.e.2, 4, 6, and 8) could be used between two adjacent intensiti measures the inconsistency of judgments by calculating the Consistency Index CI of th A consistency index $(\mathrm{CI})$ must be $<0.10$.

Although AHP is widely used, AHP is unable to address the uncertainty in the decision judgments [7]

\section{3-2 Ordered Weighted Averaging (OWA):}

To overcome the shortcomings of the AHP, OWA is used. The OWA is a family criteria aggregation procedures developed by Yager [8] as a tool for decision-making ir environment. Conventional OWA operators are of limited applicability in situations in large set of evaluation criteria, especially when the behavior of the decision-maker can range that goes from 'all the criteria have to be satisfied' to 'at least one criterion satisfied [9].

OWA involves two sets of weights: criterion, or importance weights and order The critical element of the OWA procedure is the method for obtaining the order weigh are several methods for obtaining the order weights. This study uses a fuzzy linguistic $\mathrm{q}$ approach. The concept of fuzzy linguistic quantifiers allows converting natural lange formal mathematical formulations. They can be represented as fuzzy subsets over interval with proportional fuzzy statements, such as "All of the criteria should be s ("All” for short) [10].

The Boolean overlay operations and the weighted linear combination (WLC) are often used decision rules in GIS. Boolean approaches are extreme functions that resu averse (pessimistic) solutions when the "AND" operator is used or in risk-taking (of solutions when the "OR" operator is used. The WLC approach is an averaging techn softens the hard decisions of the Boolean approach, avoiding the extremes. In a conti risk, the WLC falls exactly in the middle [11].

\section{3-3 AHP-OWA Procedures:}

The two approaches, (AHP and linguistic quantifier guided OWA), have been integr implemented in ArcGIS environment [12].

-An extension of the AHP using OWA operators (AHP-OWA) is introduced, suggesting capabilities of AHP as a comprehensive tool for decision making can be improved by in of the fuzzy linguistic OWA operators. The combination between AHP and OWA can more powerful multi-criteria decision-making tool for structuring and solving decisior problems including spatial decision problems [13].

In this method (AHP-OWA), users are first asked to use the AHP method to 1) , the hierarchical structure, and 2) obtain weights for objectives and attributes by co pairwise comparisons, then linguistic quantifier-guided OWA is used to support user's c making. Three main steps are involved at this stage: 1) specifying a linguistic quantif generating a set of ordered weights associated with $Q$, and 3) calculating the overall : each alternative using linguistic quantifier-guided OWA [14].

\section{CASE STUDY}

4.1 Background and project description:

Qassim occupies a middle position in the Arabian Peninsula, as it is locate northern center of the Kingdom of Saudi Arabia between longitudes of $41^{\circ} 30^{\prime}$ and $45^{\circ}$ : and latitudes in $24^{\circ} 25^{\prime}$ and $28^{\circ} 15^{\prime}$ north. It is the link between Riyadh area and Haa 
Formatted: Font: $8 \mathrm{pt}$, Not Bold, Complex Script Font: 8 pt, Not Bold

Formatted: Font: $1 \mathrm{pt}$, Complex Script Font: 1 pt

Formatted: (Complex) Arabic (Egypt)
Formatted: Font: $10 \mathrm{pt}$, Bold Complex Script Font: 10 pt, Bold Formatted: Space After: 0 pt, Line spacing: single

Formatted: Line spacing: Exactly 12 pt

Formatted: No underline
GIS-BASED AHP-OWA APPROACH FOR LOCATING SUITABLE SITES FOR WATER HARVESTING DAM IN C REGION, SAUDI ARABIA

North, and the city of Medina in the West direction. Figure (3) shows the Locatior Qassim case study.

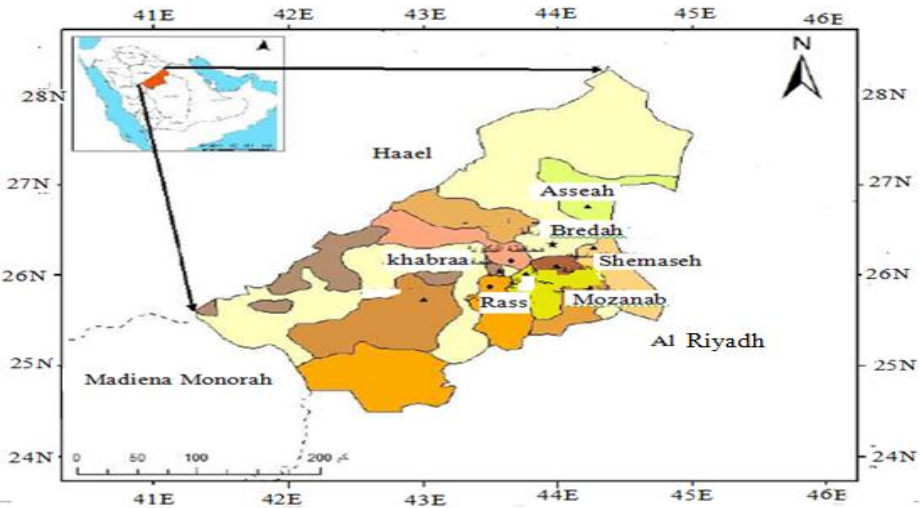

\section{Fig.3. Location of AL-Qassim region}

\subsection{Rain water Harvest Site Criteria:}

Selecting a suitable site for rain water harvesting requires the recognition $\mathrm{c}_{3}$ evaluate the abilities of different areas to be one of the suitable sites. It may be noted tha no fixed standards for all countries. Each country has its own standards, because every has its own conditions which are different from other countries. The criteria are used important standards and requirements which have been applied in similar studies. So criteria and relative sub-criteria could be extracted from experts' knowledge.

It was assumed that the criteria of rainfall harvesting site selection considered in th include three main groups; environmental (geographical), hydrological, and socio-e factors.

\section{4-2-1-Geographical criteria (Environmental factors):}

The environmental criteria in water harvesting site selection, includes:

\section{a) Slope criterion::}

Slope is an important factor in determining the water harvest site in the basin. It found that the amount of runoff or flow is proportional to the steepness of tl Experts advised not to implement harvest projects in the territory in which the of more than 5\%, where increase slope leads to difficulties during the implemen Scrape operations and flattening of land, in addition to an irregular distributic runoff [3].

b) Geologic criterion:

Geological criteria take into account the characteristics of the geological sites in the presence of the base rocks at the site and to determine the types and characteristi rocks, which help to provide the necessary construction raw materials. Water harvesting should be constructed on solid coherent rock, and as far away as possible from cracks an

\section{c) Land use criterion:}

Building water harvesting projects take into account the nature of the land use zones prefer pastoral areas for water harvesting projects. Also, they prefer it to be residential areas but not inside for several reasons, including the high cost of establis projects, considerations of public safety, environmental considerations and to en: water is not subject to pollution.

\section{d) Soil criterion:}

Soil properties affect the determination of the harvest type and the $\mathrm{m}$ construction. The soil must be thick in the water harvesting projects sites; $\mathrm{v}$ 
Formatted: Font: $8 \mathrm{pt}$, Not Bold, Complex Script Font: 8 pt, Not Bold

Formatted: Font: $1 \mathrm{pt}$, Complex Script Font: $1 \mathrm{pt}$

Formatted: (Complex) Arabic (Egypt)

Formatted: Indent: Before: $0 \mathrm{~cm}$, Line spacing: Exactly $12 \mathrm{pt}$

Formatted: No underline

Formatted: Indent: Before: $0 \mathrm{~cm}$ First line: $0 \mathrm{~cm}$, Line spacing: Exactly $12 \mathrm{pt}$

Formatted: Font: Bold, Complex Script Font: Bold

Formatted: Indent: Before: $0 \mathrm{~cm}$, Line spacing: Exactly $12 \mathrm{pt}$

Formatted: Line spacing: Exactly 12 pt

Formatted: Indent: Before: $0 \mathrm{~cm}$,

Line spacing: Exactly $12 \mathrm{pt}$

Formatted: No underline

Formatted: No underline

Formatted: Indent: Before: $0 \mathrm{~cm}$

First line: $0 \mathrm{~cm}$, Line spacing: Exactly $12 \mathrm{pt}$

Formatted: Font: $10 \mathrm{pt}$, Bold Complex Script Font: 10 pt, Bold

Formatted: Line spacing: Exactly 12 pt

Formatted: Font: 10 pt, Complex

Script Font: $10 \mathrm{pt}$

Formatted: Left, Line spacing: single

Formatted: Left, Line spacing: single

Formatted: Left, Line spacing: single

Formatted: Left, Line spacing: single

Formatted: Left, Line spacing: single

Formatted: Left, Line spacing: single

Formatted: Left, Line spacing: single

Formatted: Left, Line spacing: single

Formatted: Left, Line spacing: single

Formatted: Left, Line spacing: single

Formatted: Left, Line spacing: single

Formatted: Font: Bold, No underline, Complex Script Font: Bold

Formatted: Line spacing: Exactly 12 pt

Formatted: Indent: First line: $0 \mathrm{~cm}$ Line spacing: Exactly 12 pt
GIS-BASED AHP-OWA APPROACH FOR LOCATING SUITABLE SITES FOR WATER HARVESTING DAM IN $C$ REGION, SAUDI ARABIA

storage capacity and low permeability, silt or clay soil are the ideal soil for such [3].

\section{$\rightarrow-4-2-2-H y d r o l o g i c a l ~ f a c t o r s:$}

$\rightarrow$ In the study for locating water harvest sites, some hydrological modeling and GIS at required to obtain the pivotal elements involved in the work. These factors include: a- Drainage network:

$\rightarrow$ Rainfall harvesting structures are constructed near the valleys and on the stream.. must be located in a place where there is the most amount of water in the mai According to this, a distance near the waterways (up to $250 \mathrm{~m}$ ) is considered as appropriate distance [3].

$\rightarrow$ b- Rainfall:

One of the most important elements of climate, influences the process of selecting ap sites for water harvesting, where the sites of most rainfall are ideal areas for water hi areas while sites with less rainfall is the next appropriate sites.

\section{4-2-3- socio-economic criteria:}

These include:

$\rightarrow$ a) Distance to population and residential areas:

The water harvest must be close to population and residential areas, because the obj this project is to serve the people and cities.

b) Distance to roads:

Must consider the ease of access to the water-harvesting site, so it preferably near should be close to the main roads to reduce the economic cost of transporting wa excavations or dams to the municipal areas to serve the surrounding communit project. Table (1) depicts the main and sub criteria for a water harvest dam.

Table (1) description the main and sub criteria:

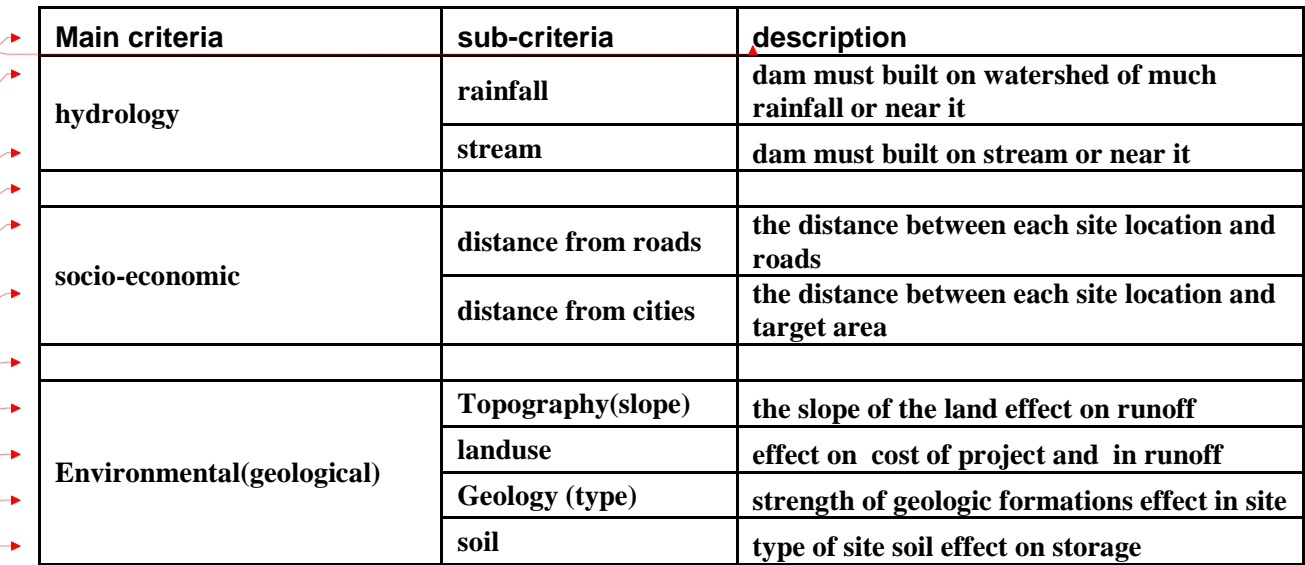

\section{1-Data Preparation:}

All the suggested criteria of rain water harvest (slope, geology, rainfall, drainage, soil, distance from roads, distance from cities) are generated using functions in GIS, and con raster having the same pixel cell size and number.

-The distance option in GIS was used to determine the straight line from both the cities as The slope map is defined from DEM obtained from Shuttle Radar Topography Mission data. In this study, the precipitation grid is obtained depending on the rain data of the st 
Formatted: Font: $8 \mathrm{pt}$, Not Bold, Complex Script Font: 8 pt, Not Bold

Formatted: Font: $1 \mathrm{pt}$, Complex Script Font: $1 \mathrm{pt}$

Formatted: (Complex) Arabic (Egypt)

GIS-BASED AHP-OWA APPROACH FOR LOCATING SUITABLE SITES FOR WATER HARVESTING DAM IN C REGION, SAUDI ARABIA

the basin. To get the spatial distribution of the rainfall, the rain data would have to be int using the Inverse Distance Weighted (IDW) method. IDW is commonly used to generat surface with precipitation data. When the method is applied, the output grid is assig similar size and number of columns and rows of the original DEM. Figure (4) shows criteria adopted in this article. Each of the layers (geology, soil, and land use) is rec according to their importance in the selection of dam site.

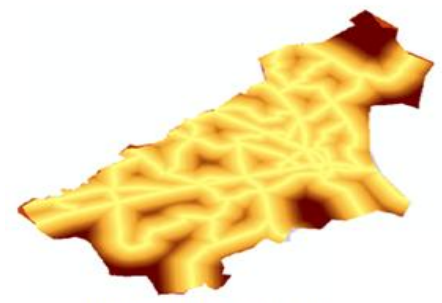

Distance from Roads

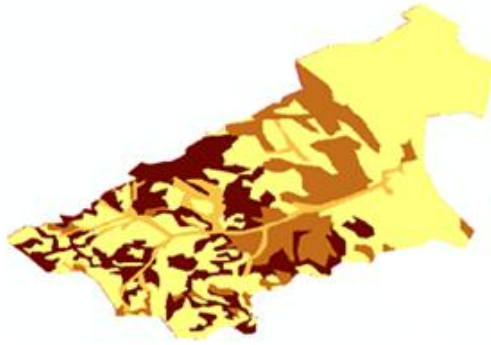

Reclassify of landuse

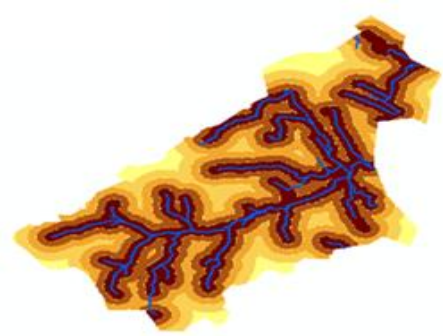

Distance from streams

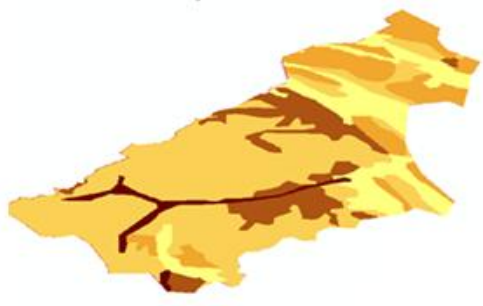

Reclassify of Soil
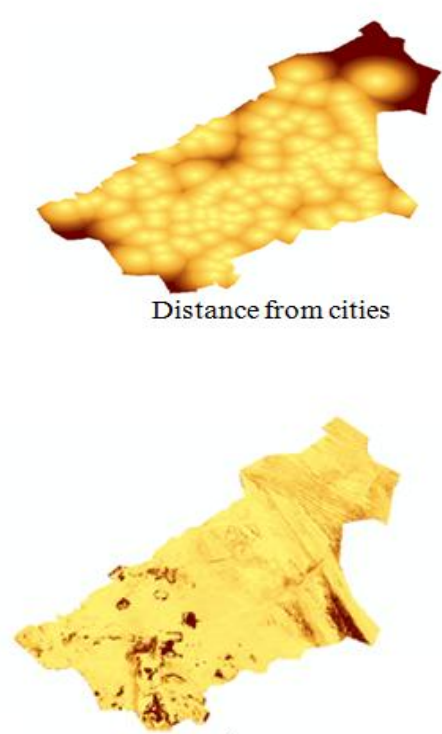

Slope

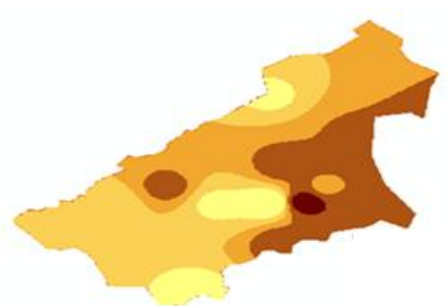

Distribution of rainfall

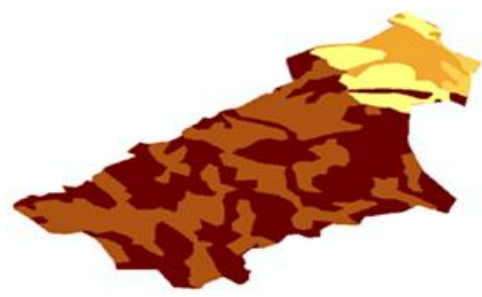

Reclassify of Geology

Fig.4. Criteria for the selection of rain water harvest location 
Formatted: Font: $8 \mathrm{pt}$, Not Bold,

Formatted: Font: $1 \mathrm{pt}$, Complex Script Font: $1 \mathrm{pt}$

Formatted: (Complex) Arabic (Egypt)

Formatted: Font: Bold, No underline, Complex Script Font: Bold

Formatted: Line spacing: Exactly 12 pt

Formatted: Indent: First line: $0 \mathrm{~cm}$ Line spacing: Exactly $12 \mathrm{pt}$ Complex Script Font: 8 pt, Not Bold

GIS-BASED AHP-OWA APPROACH FOR LOCATING SUITABLE SITES FOR WATER HARVESTING DAM IN C REGION, SAUDI ARABIA

\section{2-Standardized Criterion Maps:}

After defining the main and sub-criteria, by using Dam Site Selection toolbar in the GIS determine which criteria is maximum to goal or minimum, and select the standardized as in Figure (5). The first four criteria are to be maximized, that the suitable areas are re be located on suitable landuse, soil, slope, and geology. The distance-from-stream crit be minimized, the suitable site is where rainfall is maximum, and the distance from $\mathrm{c}$ distance from roads criteria are to be minimized.

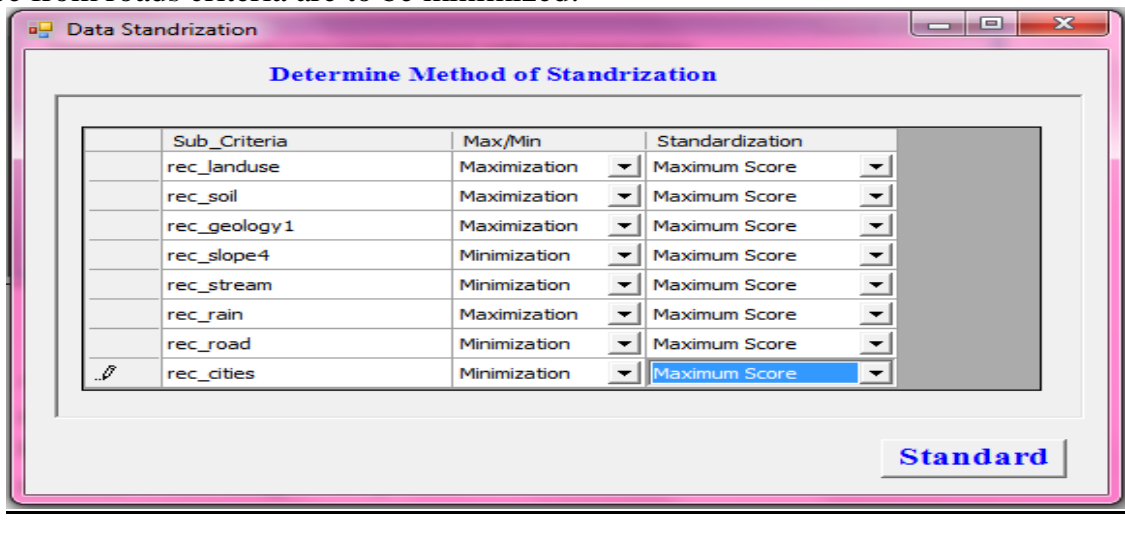

Fig.5. Data standardization

Formatted: Font: $10 \mathrm{pt}$, Bold Complex Script Font: 10 pt, Bold Formatted: Line spacing: Exactly 12 pt

Formatted: Font: Bold, No underline, Complex Script Font: Bold 
Formatted: Font: 8 pt, Not Bold, Complex Script Font: 8 pt, Not Bold

Formatted: Font: $1 \mathrm{pt}$, Complex Script Font: $1 \mathrm{pt}$

Formatted: (Complex) Arabic (Egypt)
Formatted: Font: $10 \mathrm{pt}$, Bold,

Complex Script Font: 10 pt, Bold

Formatted: Line spacing: Exactly 12 $\mathrm{pt}$
GIS-BASED AHP-OWA APPROACH FOR LOCATING SUITABLE SITES FOR WATER HARVESTING DAM IN $C$ REGION, SAUDI ARABIA

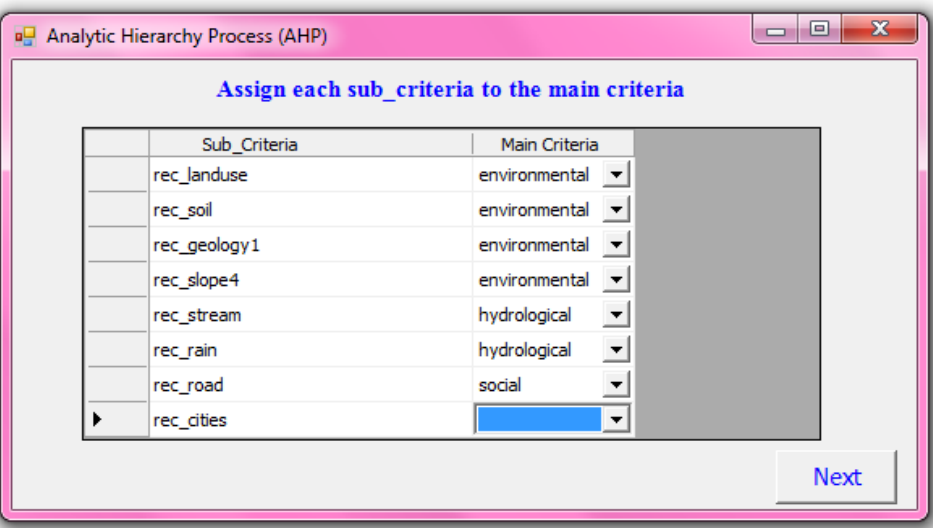

Fig .7.Main criteria and corresponding sub criteria

After building the AHP model, the relative weights for all objective clusters and thei attributes are calculated using pairwise comparisons [5]. The pairwise comparison required an expert in dams planning to provide his/her best judgments regarding the importance of objectives and attributes. In this paper, we get the important of main criteria from expert questionnaire and according to the study area. Figures from (8) to ( the pairwise comparison matrix between each main criteria and sub-criteria.

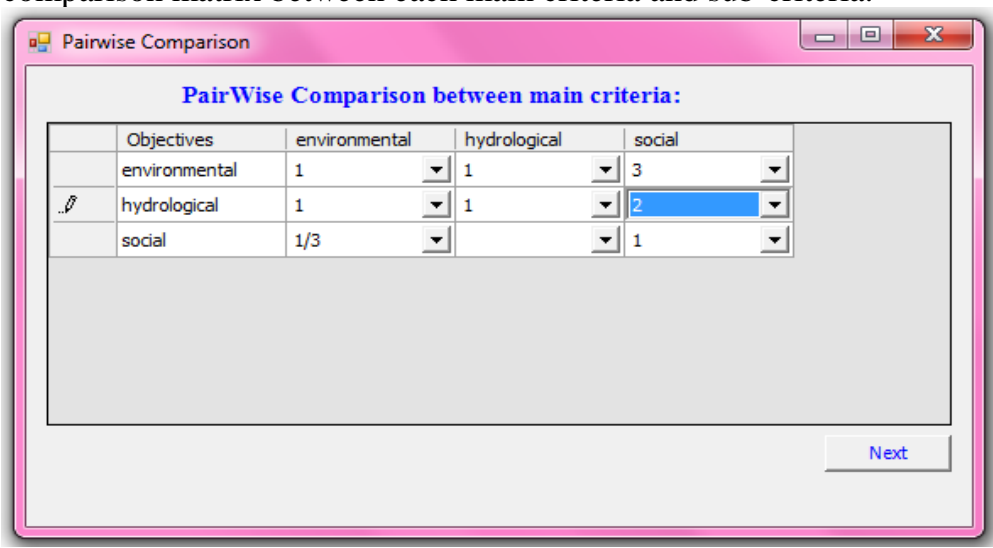

Fig.8. Pairwise comparison matrix between main criteria.

Formatted: Font: Bold, Complex Script Font: Bold

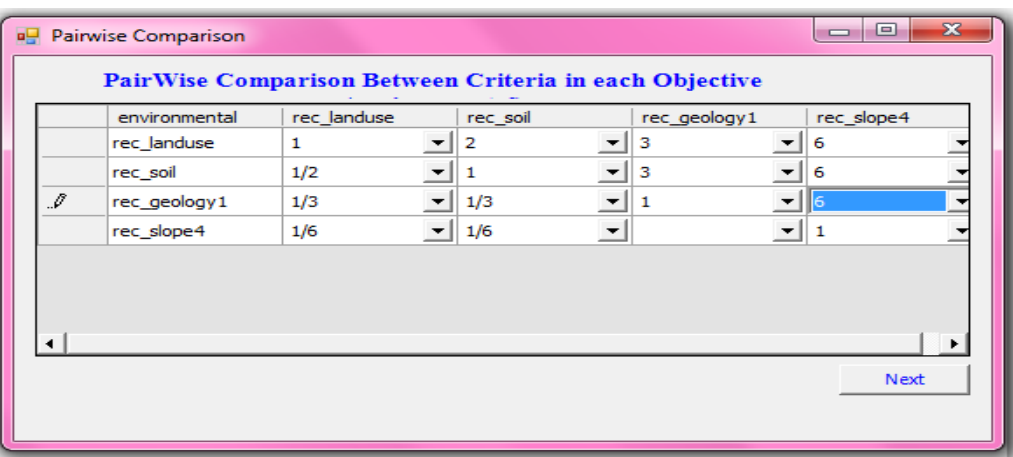


Formatted: Font: 8 pt, Not Bold, Complex Script Font: 8 pt, Not Bold

Formatted: Font: 1 pt, Complex Script Font: $1 \mathrm{pt}$

Formatted: (Complex) Arabic (Egypt)

Formatted: Font: $11 \mathrm{pt}$, Bold,

Complex Script Font: 11 pt, Bold
Formatted: Font: $11 \mathrm{pt}$, Bold Complex Script Font: 11 pt, Bold
GIS-BASED AHP-OWA APPROACH FOR LOCATING SUITABLE SITES FOR WATER HARVESTING DAM IN $C$ REGION, SAUDI ARABIA

Fig.9. Pairwise comparison matrix between sub- criteria according to environmental cri

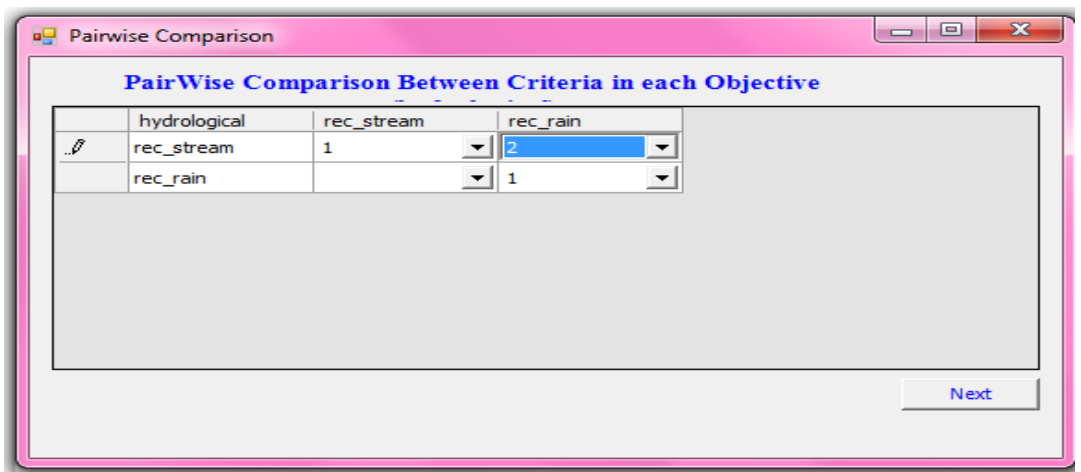

Fig.10 Pairwise comparison matrix between sub- criteria according to hydrological cri1

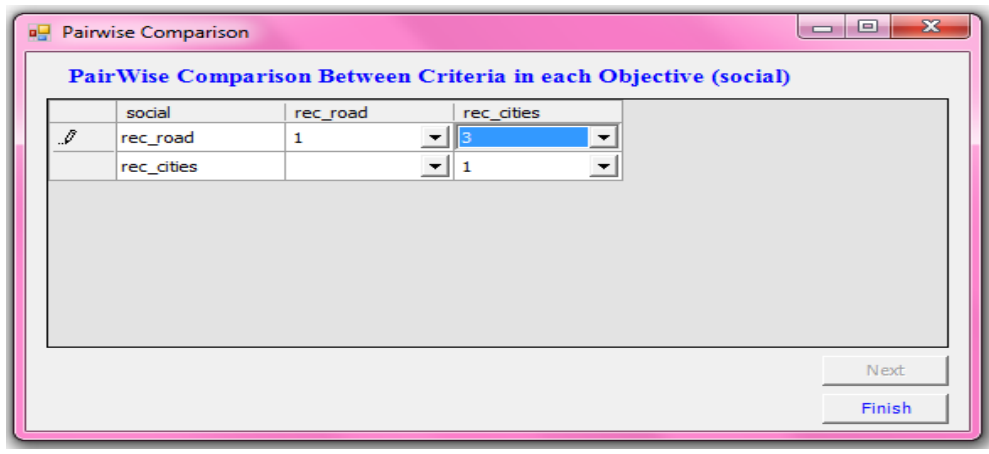

Fig.11. Pairwise comparison matrix between sub-criteria according to socio-economic criteri

\section{4-Linguistic Quantifier-Guided OWA Combination:}

Different outcomes can be generated by varying the linguistic quantifiers in $t$ OWA procedures. There are 7 linguistic quantifiers associated with the goal a objectives. Thus, theoretically $7^{(1+3)}$ alternative evaluation scenarios can be generate case study.

In this paper, different quantifiers (Some", "Half", "Many", "Most", "few" ar are used. Figures (12) to (17) show alternative land suitability zones for building $\mathrm{t}$ harvest structure.

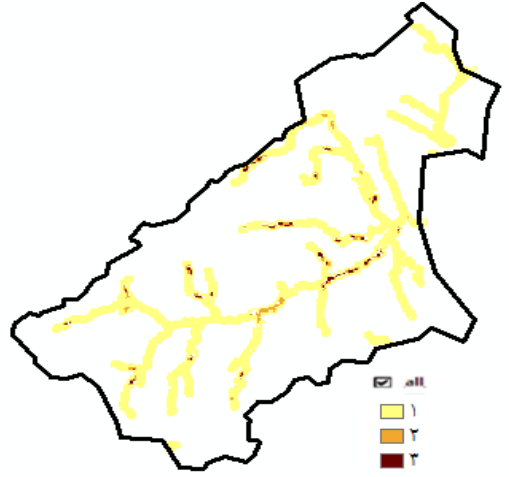


Formatted: Font: 8 pt, Not Bold, Complex Script Font: 8 pt, Not Bold

Formatted: Font: $1 \mathrm{pt}$, Complex Script Font: $1 \mathrm{pt}$

Formatted: (Complex) Arabic (Egypt)
GIS-BASED AHP-OWA APPROACH FOR LOCATING SUITABLE SITES FOR WATER HARVESTING DAM IN C REGION, SAUDI ARABIA

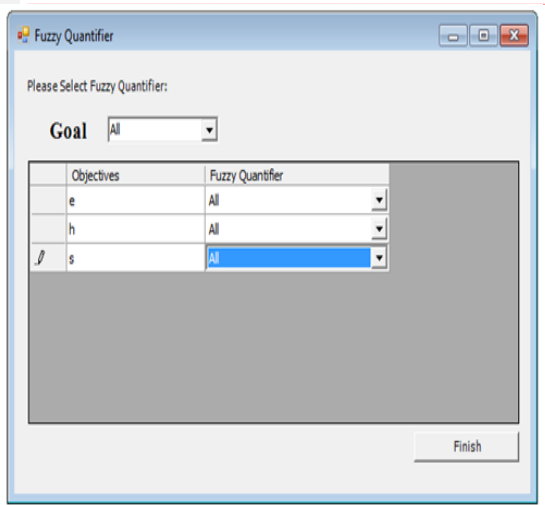

Fig.12. Site suitability for dam site using Linguistic Quantifier (all)

Formatted: Font: $10 \mathrm{pt}$, Bold, Complex Script Font: 10 pt, Bold 


\begin{tabular}{l} 
Formatted: Font: 8 pt, Not Bold, \\
Complex Script Font: 8 pt, Not Bold \\
\hline Formatted: Font: 1 pt, Complex Script \\
Font: 1 pt \\
Formatted: (Complex) Arabic (Egypt) \\
\hline
\end{tabular}

Formatted: Font: $10 \mathrm{pt}$, Bold, Complex Script Font: 10 pt, Bold

Formatted: Font: $10 \mathrm{pt}$, Bold, Complex Script Font: 10 pt, Bold
GIS-BASED AHP-OWA APPROACH FOR LOCATING SUITABLE SITES FOR WATER HARVESTING DAM IN C REGION, SAUDI ARABIA

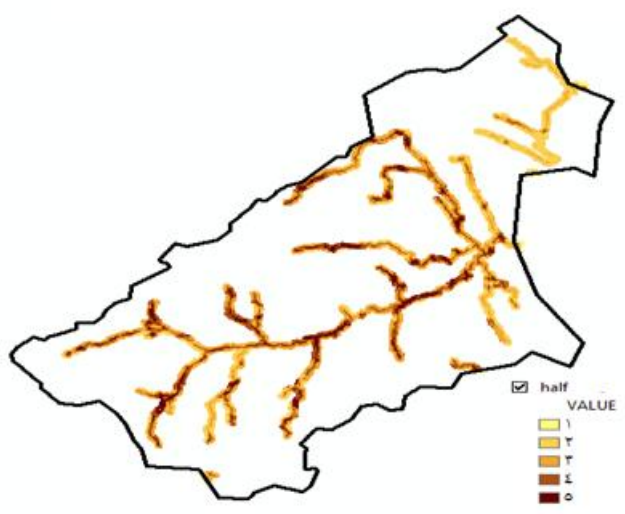

Fig.15. Site suitability for dam site using Linguistic Quantifier (half)

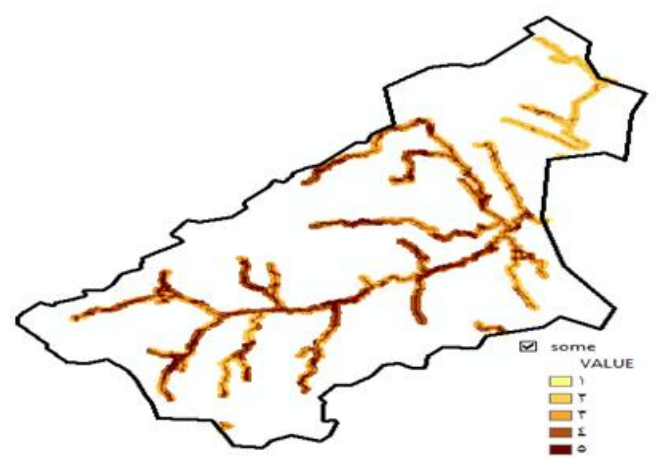

Fig.16. Site suitability for dam site using Linguistic Quantifier (some)

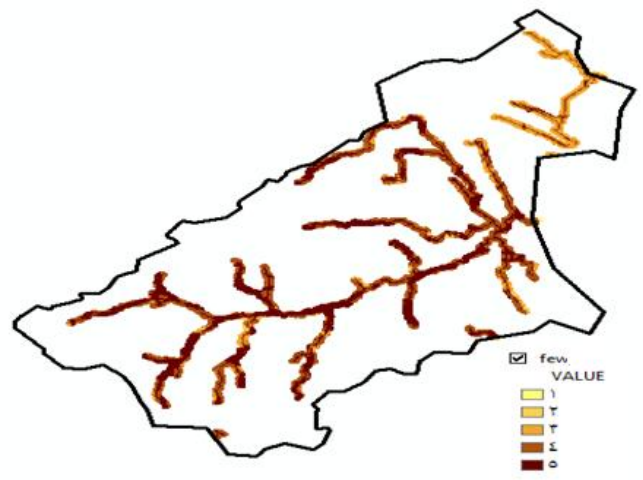

Fig.17. Site suitability for dam site using Linguistic Quantifier (few)

In $\bullet$ other words, these alternative scenarios have been developed under the assumption the linguistic quantifier associated with the goal of the decision making problem changes The linguistic terms 'Few' the results of AHP-OWA procedure show that mo study area is suitable for water harvest. 
Formatted: Font: 8 pt, Not Bold, Complex Script Font: 8 pt, Not Bold

Formatted: Font: 1 pt, Complex Script Font: $1 \mathrm{pt}$

Formatted: (Complex) Arabic (Egypt)
Formatted: Font: Bold, Complex Script Font: Bold

Formatted: Space After: $0 \mathrm{pt}$, Line spacing: Exactly $12 \mathrm{pt}$

Formatted: Line spacing: Exactly 12 pt

Formatted: Space After: 0 pt, Line spacing: Exactly $12 \mathrm{pt}$ REGION, SAUDI ARABIA

The use of linguistic term 'Half' means that equal order weights are assignt criteria. This leads to a neutral strategy. This strategy corresponds to the convention When linguistic term 'All' is applied, an extremely pessimistic strategy is adopted. It $\mathbf{r} 6$ the worst-case scenario. Under this scenario, the suitability pattern for dam site is com the worst possible outcomes.

Finally we suggested nine locations of dams for rain water harvest in Qassim 1 shown in Figure (18).

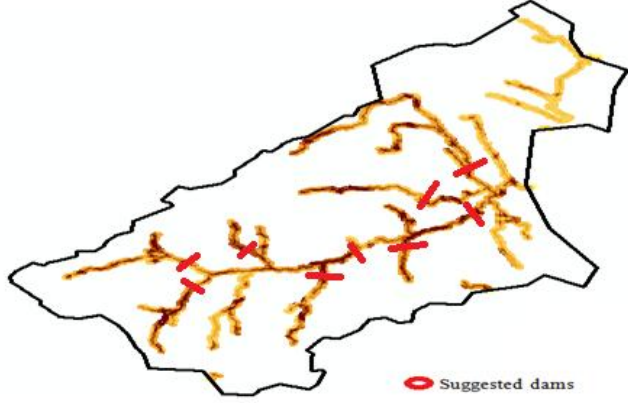

Fig.18. suggested water harvest dam site

$\rightarrow$ Model validation was done to guarantee if the model offers reliable representatior system it represented. Validation was done as follows:

a) Comparing the resulting suitability sites of AHP, OWA approach with previous stu Qassim region as in Figure (19).

$\rightarrow$ b) Visual comparisons were performed between the resulting suitability index values google images of region the comparison shows similarity with the present dams in $t$ area figure (20).

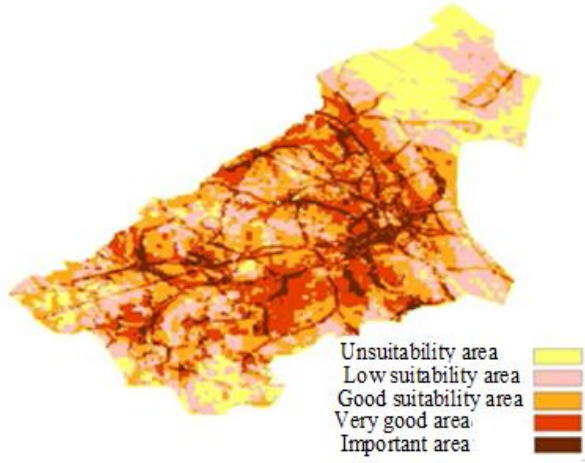

Fig.19 Site suitability for dam site using raster calculation 


\begin{tabular}{|l|}
\hline Formatted: Font: $8 \mathrm{pt}$, Not Bold, \\
Complex Script Font: 8 pt, Not Bold \\
\hline Formatted: Font: $1 \mathrm{pt}$, Complex Script \\
Font: $1 \mathrm{pt}$ \\
\hline Formatted: (Complex) Arabic (Egypt) \\
\hline
\end{tabular}

\begin{tabular}{|c|}
\hline $\begin{array}{l}\text { Formatted: Font: (Default) Calibri, } 11 \\
\text { pt, Bold, Complex Script Font: Arial, } 11 \\
\text { pt, Bold, (Complex) Arabic (Egypt), } \\
\text { Kern at } 12 \text { pt }\end{array}$ \\
\hline $\begin{array}{l}\text { Formatted: Font: (Default) Calibri, } 11 \\
\text { pt, Bold, Complex Script Font: Arial, } 11 \\
\text { pt, Bold, (Complex) Arabic (Egypt), } \\
\text { English (United Kingdom), Kern at } 12 \text { pt }\end{array}$ \\
\hline $\begin{array}{l}\text { Formatted: Font: Bold, Complex Script } \\
\text { Font: Bold }\end{array}$ \\
\hline $\begin{array}{l}\text { Formatted: Line spacing: Exactly } 12 \\
\text { pt }\end{array}$ \\
\hline
\end{tabular}

GIS-BASED AHP-OWA APPROACH FOR LOCATING SUITABLE SITES FOR WATER HARVESTING DAM IN C REGION, SAUDI ARABIA

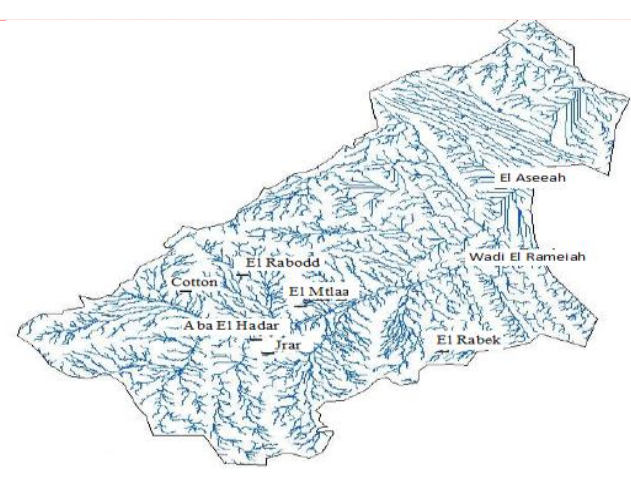

Fig.20 present dams in the study area

\section{5- SUMMARY AND CONCLUSION:}

One of the most important and complex problems in arid and semi-arid regions is a water harvest site. A large mass of information must be gathered, combined and anc make correct criteria that may effect on making the final decision. This paper has $\mathrm{F}$ the theoretical basis for a novel GIS-based MCE procedure. The paper has suggested a extension of Saaty's AHP using the fuzzy linguistic OWA operators instead of : weighted average in the process of aggregation of component satisfactions, which in tu] natural language quantification to spatial decision analysis. GIS-based MCE Dam Site : Tool has been developed as a toolbar in ArcGIS 9.3

Site selection for rain water harvest is carried out by considering the slope, $s$ use/land cover, geology, buffered stream order, distance from roads, distance from citie for decision machining.

The following conclusions are made:

1. Geographical information systems are very useful tools to determine the best loca water harvesting projects. The application of multi-criteria increases the accurac results and limits the appropriate areas of the sites selected carefully to ensure the st the project

2. The study showed that geographic information systems open the door to the introdı new criteria to locating water harvesting projects, making it easier to take the de implement water harvesting projects.

3. It has also been found that this module is a valuable and user-friendly tool. In comparison to the conventional GIS-based multicriteria evaluation methods, it giv flexibility and high efficiency for evaluating land suitability of dams. The capability generate and visualise a range resultant scenarios is particularly useful.

4. This extension allows decision-makers to define a decision strategy on a continuum pessimistic (risk-averse) and optimistic (risk-taking) strategies. Also, the pr demonstrated how, by applying different linguistic quantifiers, decision-makers cou a wide range of decision strategies and scenarios taking into accounts the level of decision-makers wish to assume in their MCE.

5. The paper has suggested a possible of AHP using the fuzzy linguistic OWA operator of a simple weighted average in the process of aggregation of component satisfactior in turn brings natural language quantification to spatial decision analysis.

6. Several alternative scenarios of site suitability for rain water harvesting have been di in this study. They show how the decision-maker's attitude involved in suitability decision-making process can influence the outcomes. 
Formatted: Font: $8 \mathrm{pt}$, Not Bold, Complex Script Font: 8 pt, Not Bold

Formatted: Font: $1 \mathrm{pt}$, Complex Script Font: $1 \mathrm{pt}$

Formatted: (Complex) Arabic (Egypt) Formatted: Line spacing: Exactly 12 pt

Formatted: Font: (Default) Times New Roman, 12 pt, Complex Script Font: Times New Roman, 12 pt

Formatted: No underline, (Complex) Arabic (Saudi Arabia)

Formatted: List Paragraph, Justified, Line spacing: Exactly $12 \mathrm{pt}$

Formatted: Font: Not Bold, Complex Script Font: Not Bold, English (United States)

Formatted: Font: Not Bold, Complex Script Font: Not Bold, English (United States)

Formatted: Font: Not Bold, Complex Script Font: Not Bold, English (United States)

Formatted: Font: Not Bold, Complex Script Font: Not Bold, English (United States)

Formatted: Font: Not Bold, Complex Script Font: Not Bold, English (United States)

Formatted: Font: Not Bold, No underline, Complex Script Font: Not Bold, (Complex) Arabic (Saudi Arabia)

Formatted: (Complex) Arabic (Saudi Arabia), English (United States)

Formatted: List Paragraph, Indent: Before: $-0.5 \mathrm{~cm}$, Line spacing: Exactly $12 \mathrm{pt}$

Formatted: Font: (Default) Times New Roman, 12 pt, Complex Script Font: Times New Roman, 12 pt, English (United States)

Formatted: Font: (Default) Times New Roman, 12 pt, Complex Script Font: Times New Roman, 12 pt, English (United States)

Formatted: Font: (Default) Times New Roman, 12 pt, Complex Script Font: Times New Roman, 12 pt, English (United States)

Formatted: Font: (Default) Times New Roman, 12 pt, Complex Script Font: Times New Roman, 12 pt
GIS-BASED AHP-OWA APPROACH FOR LOCATING SUITABLE SITES FOR WATER HARVESTING DAM IN $C$ REGION, SAUDI ARABIA

7. $\rightarrow$ As a result, this work could be taken further by conducting field validation in compare and technically evaluate all the candidate sites in terms of their envir impact assessment, from which the top ranking sites will undergo further geotechı hydro-geological detailed investigations.

\section{REFERENCE:}

[1] Ramakrishnan, A Bandyopadhyay and K N Kusuma (2009): „SCS-CN and GISapproach for identifying potential water harvesting sites in the Kali Wa-tershed, Ma Basin, India"e Journal of Earth System Science, 118, No. 4, August 2009, pp. 355-368.

[2] Nihila A,2012 " Water Poverty Index Mapping And GIS-BASED Approach For Id Denitrifying Potential Water Harvesting Sites ", International Journal of Remote Se Geoscience (IJRSG)

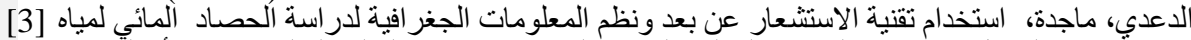

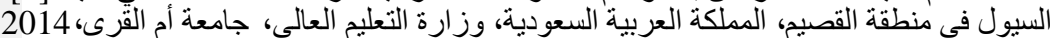

[4] Harish (2014)," Site Suitability Analysis of Water Harvesting Structures Using Sensing and GIS - A Case Study of Pisangan Watershed, Ajmer District, Rajasthi International Archives of the Photogrammetry, Remote Sensing and Spatial Inf Sciences, Volume XL-8, 2014 ISPRS Technical Commission VIII Symposium, ( December 2014, Hyderabad, India

[5] Eldrandaly K. , 2013” Developing a GIS-based MCE Site Selection Tool in ArcGIS COM Technology", ", IAJIT ,Vol.10, No.3.

[6] T. L. Saaty, 1980 "The Analytic Hierarchy Process," McGraw--Hill, New York.

[7] H. Deng, 1999 "Multi-Criteria Analysis with Fuzzy Pairwise Comparisons," Inte Journal of Approximate Reasoning, Vol. 21, pp. 215-231.

[8] Yager, R., 1988. On ordered weighted averaging aggregation operators in mult decision making. IEEE Transactions on Systems, Man and Cybernetics, 18 (1), 183-190

[9] Yager, R., 1996. Quantifier guided aggregation using OWA operators. Internationa of Intelligent Systems, 11, 49-73

[10] Yager, R., 1997, "On the Inclusion of Importances in OWA Aggregation," In: R. and J. Kacprzyk, Eds., The Ordered Weighted Averaging Operators: Theory and app] Kluwer Academic Publishers, Boston, pp. 41-59.

[11] Eldrandaly, , 2013"Exploring multi-criteria decision strategies in GIS with lis quantifiers: an extension of the analytical network process using ordered weighted a operators" , International Journal of Geographical Information Science, Vol. 27, No. 1 2482

[12] Yager R. and Kelman A, 1999, "An Extension of the Analytical Hierarchy Proce OWA operators," Journal of Intelligent and Fuzzy Systems, vol. 7, no. 4, pp. 401-417.

[13] Khalid, " Developing a GIS-Based MCE Site Selection Tool in ArcGIS Usir Technology" The International Arab Journal of Information Technology, Vol. 10, No 2013

[14] Menget.al, , 2011" A GIS-Based Multicriteria Decision Analysis Approach for Accessibility Patterns of Housing Development Sites: A Case Study in Canmore, Journal of Geographic Information System, 3, 50-61 doi:10.436/jgis.2011.31004 F Online January,2011 (http://www.SciRP.org/journal/jgis)

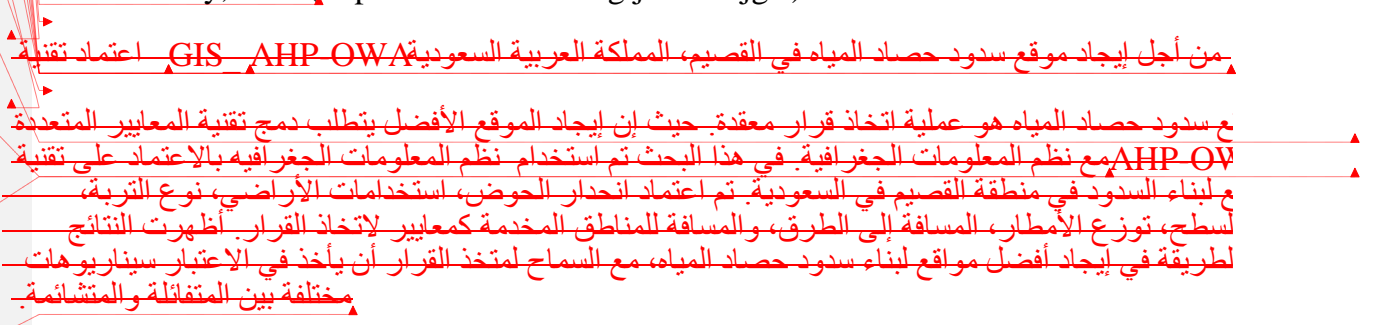

